\title{
Farmers' Perceptions of Climate Change, Long-term Variability and Trends in Rainfall in Apac District, Northern Uganda
}

Francis Atube ( $\square$ atube12frak@gmail.com )

Gulu University Faculty of Education and Humanities https://orcid.org/0000-0001-6180-8239

Geoffrey M. Malinga

Gulu University Faculty of Science

Martine Nyeko

Gulu University Faculty of Agriculture and Environment

Daniel M. Okello

Gulu University Faculty of Agriculture and Environment

\section{Basil Mugonola}

Gulu University Faculty of Agriculture and Environment

George William Omony

Uganda National Meteorological Authority

Ipolto Okello-Uma

Gulu University Faculty of Agriculture and Environment

\section{Research}

Keywords: Rainfall, Abrupt change point, Upper limit, Lower limit, Sequential Mann-Kendall test statistics

Posted Date: April 26th, 2021

DOl: https://doi.org/10.21203/rs.3.rs-450998/v1

License: (c) (i) This work is licensed under a Creative Commons Attribution 4.0 International License.

Read Full License 
1 Farmers' perceptions of climate change, long-term variability and trends in rainfall in Apac district, Northern Uganda

3

4 Francis Atube ${ }^{1 *}$, Geoffrey M. Malinga², Martine Nyeko ${ }^{3}$, Daniel M. Okello ${ }^{4}$, Basil

$5 \quad$ Mugonola $^{4}$, George William Omony ${ }^{5}$ and Ipolto Okello-Uma ${ }^{6}$

6

$7 \quad{ }^{1}$ Department of Science Education (Agriculture), Faculty of Education and Humanities, Gulu 8 University, P.O. Box 166, Gulu, Uganda

$9 \quad{ }^{2}$ Department of Biology, Faculty of Science, Gulu University, P.O. Box 166, Gulu, Uganda

$10{ }^{3}$ Department of Biosystems Engineering, Faculty of Agriculture and Environment, Gulu

11 University, P.O. Box 166, Gulu, Uganda

${ }^{4}$ Department of Rural Development and Agribusiness, Faculty of Agriculture and

Environment, Gulu University, P.O. Box 166, Gulu, Uganda

${ }^{5}$ Directorate of Forecasting Services, Uganda Meteorological Authority, P.O. Box 7025,

Kampala, Uganda

${ }^{6}$ Department of Food Science and Postharvest Technology, Faculty of Agriculture and

Environment, Gulu University, P.O. Box 166, Gulu, Uganda

*Corresponding author: atube12frak@gmail.com

\section{Abstract}

Background: Climate change poses a serious threat to agricultural livelihoods and food security of smallholder farmers in Sub Saharan Africa. Understanding long-term rainfall trends of variability and extremes at local scales and perceptions regarding long-term changes in climate variables is important in planning appropriate adaptation measures to climate 
change. This paper examines the perception of farmers in Apac district regarding long-term

changes in climate variables and analyzes the trend of occurrence in seasonal and annual rainfall in Apac district, northern Uganda. A cross-sectional survey design was employed to collect data on perception of farmers regarding long-term changes in climate from 260 randomly selected small-holder farmers' households across two sub-counties in Apac district by the administration of semi-structured questionnaires in February 2018. Monthly rainfall data sets from the Uganda Meteorological Authority (UMA) for the period 1980 to 2019 for the Apac district were also used to analyze trends of occurrences in seasonal and annual rainfall in the study area. The nonparametric Sequential Mann-Kendall (SMK) and Sequential SMK tests were employed at a 5\% significance level to detect trends and abrupt change points in mean seasonal rainfall.

Results: The majority of the respondents $(87 \%)$ perceived a decrease in precipitation over the past 39 years. The plot of forward regression $u\left(t_{i}\right)$ values and backward regression $u^{\prime}\left(t_{i}\right)$ values showed interactions indicating rainfall trends: rainfall lower and upper limits and abrupt change points in the different cropping seasons. Analysis of historical series of mean monthly and annual rainfall showed an abrupt change in rainfall in March, April, May (MAM) season in 1982. Although the September, October and November (SON) season did not show an abrupt significant change, there was a significant $(\mathrm{p}<0.05)$ increase in rainfall above the upper limit from 1994 to date.

Conclusion: The mean seasonal rainfall for MAM and SON cropping seasons in the Apac district were highly variable from different time points within the past 39 years (1980-2019), while JJA did not realize a significant change in rainfall within the same study period. Thus, the two cropping seasons (MAM and SON) in the district experienced remarkable variations in rainfall. This, therefore, provides a basis for Government to strengthen the provision of an effective climate tailored agricultural advisory service to aid farmers' adaptation planning at 
the local level and to assist smallholder farmers and land-use managers in developing effective adaptation management strategies to the effects of climate change.

Keywords: Rainfall, Abrupt change point, Upper limit, Lower limit, Sequential MannKendall test statistics

\section{Introduction}

The smallholder farming communities in Africa face a wide range of climate change challenges which present in the form of unpredicted weather conditions, extended droughts and floods. Many studies (Igodan et al. 1990; Mendelsohn. 2006; Mendelsohn. 2008; Esham et al. 2013) have identified Sub Saharan Africa (SSA) as one of the regions most vulnerable to the negative impacts of climate change compared to other regions. This is because of the low levels of adaptation and/or mitigation capacity and poverty of farmers in SSA (Bagamba et al. 2012; Krämer et al. 2013). Inadequate capacity to adapt to the effects of climate change has resulted in global food insecurity which remains a worldwide concern for the next 50 years and beyond (Rosegrant et al. 2003). The study of precipitation trend over the African continent reveals that while there is a statistically significant increasing annual precipitation trend over most parts of West Africa, the horn of Africa which includes the East African Region shows a significantly decreasing precipitation trend (Omondi et al. 2014). The major drivers of these inter-annual climate variations in Africa include El Nino South Oscillation (ENSO) which are as a result of large scale changes in atmosphere and Ocean that influence conditions over many regions of the world; the Tropical North Atlantic (TNA) oceanatmosphere interaction which influences the monsoon rainfall over the Sahel; Tropical south Atlantic (TSA) which is the Sea Surface Temperature (SST) variability that affects the Sahel, the Gulf of Guinea and the tropical eastern Atlantic coasts of Africa; the Tropical Atlantic Sea Index (TASI) which represents a mode of SST variability in the Atlantic Ocean; the 
Indian Ocean Dipole which is the variability between the western and eastern part of the Indian Ocean; and the Tropical cyclones in the Southwestern Indian Basin (Marchant et al. 2007; Ogwang et al. 2018). These decreasing precipitation trends experienced in the horn of Africa are known to have adverse effects on agricultural productivity in the region (Kamga et al. 2019).

The tropical East African region experiences much variation in the distribution of precipitation resulting in a complex seasonal cycle. Many parts of the region experience two peaks of rainfall seasons that are normally associated with solar heating maxima in the equinox seasons, SST forces, topography and teleconnections to the West African and Indian monsoon systems (Kerry et al. 2013).

The intertropical Convergence Zone plays a great role in determining rainfall patterns in East Africa (Phillip et al. 2000) which is explained by the movement of the overhead sun over the equator. The sun passes overhead the equator twice a year making most parts of the East African region experience a bimodal rainfall regime. The first season occurs from March to May, and the second season from October to December. These two rainy seasons come with the north-easterly winds originating from the Indian Ocean (Ogallo 1988; Mutai et al. 1998). In Uganda, particularly the northern part, the period between the first season and the onset of the second season is short making it considered as a unimodal rainfall regime (Mubiru et al. 2012). Rains in northern Uganda usually start as early as the third week of March, although it is typical for it to start in the first week of April. According to Campozano et al. (2016), unimodal rainfall regimes are as a result of the orographic effect which occurs mainly at the extremes of the water basins. For areas near the equator, the seasonal pattern generally follows the bimodal system and tends to a unimodal system with increasing distance from the equator (Conway et al. 2005; Asadullah et al. 2008). Northern Uganda being away (219.5 $\mathrm{km}$ ) from the equator and on the higher side of the Lake Victoria basin (UBOS. 2014), is 
expected to have a unimodal rainfall regime. The orographic effect from the Lake Victoria basin to the highlands of northern Uganda also puts the region on the unimodal rainfall regime since it is located at the edge of the basin.

The unimodal rainfall regime of northern Uganda is blessed with three cropping seasons, the first begins in March, through April and ends in May (MAM); the second begins in June, July and ends in August (JJA) while the third is from September, through October to end of November (SON) (Funk et al. 2012; Mubiru et al. 2012). The orographic effect from the Lake Victoria basin, together with the migration of the overhead sun in the northern hemisphere results in a unimodal rainfall regime in the region with rainfall occurring almost throughout the year (Okoola 1996). The dry season is felt in the months of December, January up to the end of February. Inter-annual variation in climate includes droughts, floods, variation in the timing of onsets and cessation of rainy seasons, uncertain rainfall durations and seasonal precipitation. A study conducted in Northern Uganda by USAID in 2014 reveals that the onset of the rainy season is perceived by farmers to delay compared to the past, while cessation of the rainy season arrives earlier, with fewer rainy days and sometimes highintensity rainfall resulting to floods (USAID 2014).

Previous studies on inter annual rainfall variations in the East African region made use of the regional indices which may not necessarily capture climate events over local scales such as in northern Uganda due to the influence of many local factors (Ogwang et al. 2016; Mubiru et al. 2012) yet climate change adaptation needs are location specific (Atube et al. 2021). The lack of information on climate events at the local scale has had adverse effects on smallholder farmers who depend on rainfall to supply the required water for their small farms. The generation of agronomically relevant seasonal rainfall characteristics is important in enhancing knowledge and guiding decisions on climate change adaptation and mitigation 
measures. This is particularly important for Apac district which is located in the cattle corridor where there is a high incidence of poverty and whose farming population are predominantly smallholders who depend on rain fed agriculture for their livelihoods. This paper explores farmers' perceptions of climate change, and analyzes the variability and trends in overall annual and seasonal rainfall pattern for the months of March-April-May (MAM), June-July August (JJA) and September-October-November (SON) in Apac district, Northern Uganda over the period 1980 to 2019. This is expected to provide a basis for planning provision of effective climate tailored agricultural advisory service to aid farmers' adaptation planning at the local level. The study is also expected to assist smallholder farmers and land use managers in developing effective adaptation management strategies.

\section{Methodology}

\subsection{Study Area}

The study was conducted in Apac district, which is located in northern Uganda (Fig. 1). The district covers a total area of 3,908 $\mathrm{km}^{2}$, of which $9 \%$ is covered by swamps and water bodies while $15 \%$ is covered by forests, leaving $2,970 \mathrm{~km} 2$ for farming and human settlement (UBOS 2009). The district lies between longitudes $32^{\circ} \mathrm{E}$ and $34^{\circ} \mathrm{E}$ and latitudes $2^{\circ} \mathrm{N}$ and $3^{\circ}$ $\mathrm{N}$ and is bordered by Lake Kwania and river Nile in the south. Apac district is located in the cattle corridor that stretches from Southwestern to Northeastern Uganda and is dominated by pastoral rangelands (Nimusiima et al. 2019). The area is characterized by semi-arid climate with a uni-modal rainfall pattern. The mean annual rainfall is about $1,330 \mathrm{~mm}$, which falls predominantly from April to November with peaks in April and October. The dry season is from December to March and the average monthly minimum and maximum temperatures are $17^{\circ} \mathrm{C}$ and $29^{\circ} \mathrm{C}$, respectively (UBOS 2016). The farming system in Apac district is predominantly mixed small-scale cropping and livestock rearing (UBOS 2014; 2017). The 
dominant vegetation cover in the district is of the dry savannah type comprising mainly

152

153

154

155

Hyperrhenia rufa, Terminalia superba, Acaciahockii and Butterspermum species. It also has isolated riverine vegetation along river Nile and other areas dominated by wetland plants (UBOS 2009; NEMA 2001).

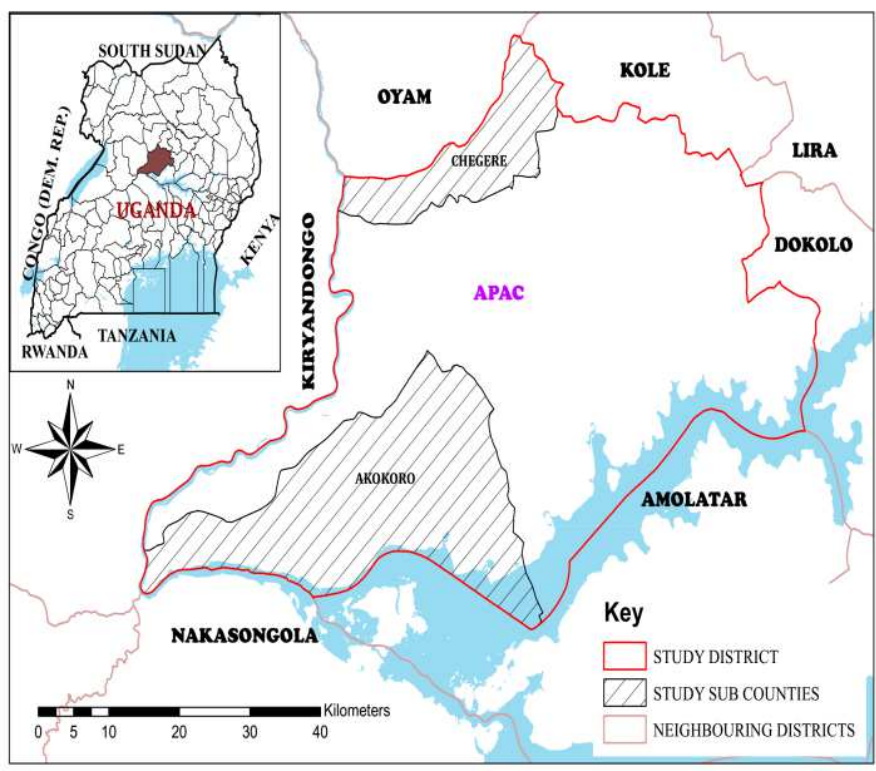

Fig.1. Location of Apac district in Uganda.

\subsection{Data collection}

\subsubsection{Data on perception}

We collected primary data on perception using household surveys. The target population of smallholder farmers was selected using a multistage sampling technique. First, Apac district was purposively selected based on the limited researched information regarding the perception of smallholder farmers on climatic change, and the highly agrarian nature of their population and location in the cattle corridor. The livestock sector in this study is key because of its contribution to Uganda's growing economy, contributing an average of $4.2 \%$ to the national Gross Domestic Product (GDP) in recent years (Uganda Bureau of Statistics (UBOS 2017). From the district, two sub-counties; Akokoro and Chegere were randomly selected. In each of the selected Sub-counties, two parishes were randomly selected totaling to four 
parishes. From each of the parishes, one village was randomly selected making a total of four villages for the entire study. Finally, 260 households (Krejcie \& Morgan 1970) were randomly and proportionally selected from the four villages. A cross-sectional survey (conducted from December 2018 to May 2019) was employed to collect primary data from farming household heads. The survey was piloted at Paicho Sub County in Gulu district with 20 farmers (13 males and 7 females). The surveys were carried out by trained data enumerators. The primary data obtained included data farmer's perception on key aspects related to rainfall variability. During the interviews we explored farmers' perception of climate change over the past 39 years (1980-2019). Respondents were asked whether they had noted any changes (increase, decrease, no change) in the weather pattern over the last three decades.

\subsubsection{Climate data}

The historical monthly rainfall data for Apac (recorded from only one meteorological station located in Apac district headquarters) was provided by the Uganda Meteorological Authority (UMA) for the period 1980-2019. This data was also grouped into three different rain seasons; first (March-April-May), second (June-July-August) and third rainy seasons (September-October-November).

\subsection{Data analyses}

\subsubsection{Primary data}

Survey data from respondents were analyzed using descriptive statistics (means, frequencies, percentages) package found in the statistical package for social scientists (SPSS) computer software version 25. This statistical package was used to summarize and categorize 
information gathered from farmers on onset and cessation of rains and duration of seasons to identify the perception of farmers on climate change.

\subsubsection{Estimation of missing rainfall data}

The level of advancement in technology and changes in observation routines of rainfall records can affect the quality of the meteorological records. Additionally, other challenges such as political instability, poor maintenance of weather stations and inadequate technical capacity have resulted into poor record keeping and inconsistencies in Uganda's meteorological data (Anderson et al. 2009). This situation has led to gaps in rainfall data for Apac, which needs to be addressed. In this study, the arithmetic mean method was used to estimate missing monthly rainfall data since the normal monthly precipitation of similar months were within the range of $10 \%$ of the normal monthly precipitation of the missing monthly data (Chow et al. 1988).

\subsubsection{Rainfall trend analyses}

Sequential non-parametric Mann-Kendall (SMK) test in Fortran software was employed on the monthly average data-sets to identify discontinuities and abrupt change points that indicate the starting year of the trend in the data series. SMK is a valid and widely used method for detection of trends in climatic time series data (Chatterjee et al. 2013; Khalid et al. 2016). It is most preferred because of its insensitivity to outliers and tendency to take care of the skewed distribution of data. The significance of trend was determined at $95 \%$ confidence interval.

213 To prevent seasons of maximum variance from being pre-dominant, data were normalized prior to analysis. The standardized rainfall anomaly $\mathrm{z}$ was computed from:

$$
Z=\frac{X-\bar{X}}{s_{d}}
$$


$237 E\left(t_{i}\right)=\frac{i(i-1)}{4}$ denoted by $n_{i}$.

$t_{i}=\sum_{j=1}^{i} n_{i}$

Where X denotes observed MAM, JJA and SON rainfall, $X$ bar is the long term mean for MAM, JJA and SON rainfall $\mathrm{S}_{\mathrm{d}}$ is the standard deviation in the MAM, JJA and SON rainfall.

The value of $\mathrm{Z}$ provides instantaneous information about the deviation from the mean.

\subsubsection{Temporal variability of the seasonal rainfall pattern}

The seasonal rainfall totals were normalized following equation 1 for several reasons: First was to identify years with extreme or suppressed rainfall over the study period during the rainfall seasons in the study area, second to present the temporal variations of indices from which extreme peak years were identified and lastly was to obtain seasonal rainfall indices on an interannual scale.

\subsubsection{Sequential Mann-Kendall Test Statistic}

The Sequential version of the Mann-Kendall test statistic (Sneyres 1990) on time series $x_{i}$ detects recognized event or change points in long-term time series. The Sequential MannKendall test was computed using the ranked values, $y_{i}$ of the given time series $\left(x_{1}, x_{2}, x_{3}, \ldots . x_{n}\right)$. The magnitudes of $y_{i}(i=1,2,3, \ldots \ldots \ldots, n)$ are compared with $y_{j}$ $(j=1,2,3, \ldots \ldots \ldots, j-1)$. For each comparison, the cases where $y_{i}>y_{j}$ were counted and

A statistic $t_{i}$ was defined as:

The distribution of test statistics $t_{i}$ has a mean specified as:

and variance specified as

$\operatorname{Var}\left(t_{i}\right)=\frac{i(i-1)(21+5)}{72}$ 
240 The sequential values of a reduced or standardized variable, called statistic $u\left(t_{i}\right)$ was

241 calculated for each of the test statistic variable $t_{i}$ as follows:

$242 u\left(t_{i}\right)=\frac{\left[t_{i}-E\left(t_{i}\right)\right.}{\sqrt{\operatorname{var}\left(t_{i}\right)}}$

243

244

245

246

247

while the forward sequential statistic $\left(u\left(t_{i}\right)\right)$ was estimated using the given time series $\left(x_{1}, x_{2}, x_{3}, \ldots x_{n}\right)$, the values of the backward sequential statistic $\left(u^{\prime}(t)\right)$ were computed in the same manner but starting from the end of the series. When estimating the $u^{\prime}(\mathrm{t})$, the time series is sorted so that the last value of the original time series comes first $\left(x_{1}, x_{2}, x_{3}, \ldots x_{n}\right)$.

The sequential version of the Mann-Kendall test statistic allows detection of the approximate beginning of a developing trend. When $u\left(t_{i}\right)$ and $u^{\prime}(t)$ curves are plotted, the intersection of the curves $u\left(t_{i}\right)$ and $u^{\prime}(t)$ locates approximate potential trend turning point. If the intersection of $u\left(t_{i}\right)$ and $u^{\prime}(t)$ occurs within + or -1.96 (5\% level) of the standardized statistic, a detectable change at that point in the time series can be inferred. Moreover, if at least one value of the reduced variable is greater than a chosen level of significance of Gaussian distribution, the null hypothesis $\left(\mathrm{H}_{0}\right.$ : Sample under investigation shows no beginning of a new trend) is rejected.

\subsection{Results and Discussion}

\subsection{Farmers' perceptions of climate change}

Farmers generally perceived climate change in terms of extreme weather events, number of pest and disease attacks, availability of rain water, the intensity of rain, number of rain days, duration of rain period, amount of rain, frequency of rain, variation in the onset of rain period, variation in cessation of rain period and the number of hot days/drought. The results of the study showed that almost $88 \%$ representing 232 farmers/ respondents interviewed across the district perceived an increase while only $6 \%$ perceived a decrease in number of 
hot days/droughts over the past three decades (Table 2). A total of $6 \%$ of farmers perceived no change in hot days. The majority of respondents perceived an increased number of pest and disease attacks (86\%), increased number of extreme weather events (72\%), while (47\%) reported increased variation in onset of rain period. The majority of respondents reported a decrease in the number of rain days $(88 \%)$, frequency of rain $(87 \%)$, amount of rain $(87 \%)$, intensity of rain $(82 \%)$, availability of rain water $(79 \%)$, duration of rain period $(76 \%)$, (Table 2). Only a few (between 5 to $14 \%$ ) farmers reported no change in climate for the past three decades. The results of this study imply that farmers are well aware of climate change, as majority ( $>80 \%$ of the farmers) interviewed admitted to observing a decreasing trend in the amount and intensity of precipitation. This corroborates findings of Oluwatimilehin and Ayanlade (2021), ) and Juana et al. (2013) Fosu-Mensah et al. (2012), who reported that the majority of the respondents in Ondo and Ogun states, Nigeria, in Ghana and in Eastern particularly decreased precipitation.

Table 2. Farmer's perceptions on climate change in Apac district

\begin{tabular}{|l|l|l|l|l|l|l|}
\hline Response & \multicolumn{2}{|l|}{ Increased } & \multicolumn{2}{l|}{ Decreased } & \multicolumn{2}{l|}{ No change } \\
\hline & $\mathbf{N}$ & $\mathbf{\%}$ & $\mathbf{N}$ & $\mathbf{\%}$ & $\mathbf{N}$ & $\mathbf{\%}$ \\
\hline No. of extreme events & 191 & 72.1 & 38 & 14.4 & 36 & 13.6 \\
\hline No. of pest and disease attacks & 227 & 85.6 & 19 & 7.1 & 19 & 7.2 \\
\hline Availability of rain water & 23 & 8.6 & 208 & 78.5 & 34 & 12.8 \\
\hline Intensity of rain & 24 & 9.0 & 216 & 81.5 & 25 & 9.4 \\
\hline No. of rain days & 7 & 2.6 & 233 & 87.9 & 25 & 9.4 \\
\hline Duration of rain period & 19 & 7.1 & 201 & 75.8 & 45 & 17 \\
\hline Amount of rain & 14 & 5.3 & 230 & 86.8 & 21 & 7.9 \\
\hline Frequency of rain & 10 & 3.7 & 231 & 87.2 & 24 & 9.1 \\
\hline Variation in onset of rain period & 124 & 46.8 & 115 & 43.2 & 26 & 9.8 \\
\hline Variation in cessation of rain period & 106 & 40 & 145 & 54.7 & 14 & 5.3 \\
\hline No. of hot days/Drought & 232 & 87.5 & 16 & 6.1 & 17 & 6.4 \\
\hline
\end{tabular}

281 To verify the farmers' perceived long-term change in rainfall, the historical annual mean 282 rainfall data for the study area from 1980 to 2019 (39 years) were analyzed. 


\subsection{Seasonal rainfall patterns of the study area}

286

The normalized indices for March, April, May (MAM), June, July, August (JJA) and September, October, November (SON) seasons generated from consistent seasonal rainfall totals over the study period are presented in Appendix 1. This study finding showed that there was variability in MAM, JJA and SON rainfall seasons and that they were quite independent of one another. For this reason, the seasonal rainfall pattern of the three rainfall seasons were presented separately. To understand the rainfall pattern of MAM over Apac district, the standard anomaly of MAM rainfall (Fig. 1) was examined. Results show that the highest mean MAM rainfall over the period 1980-2019 was observed in 1983 (extremely wet), while the least amount was noted in 2000 (extremely dry). However, based on the standard deviation of MAM rainfall of $\geq 1$ (for wet years) and $\leq 1$ (for dry years) (Ogwang et al. 2018), three wet years were observed over the study period, while two dry years were noted for the same study period (Fig.1).

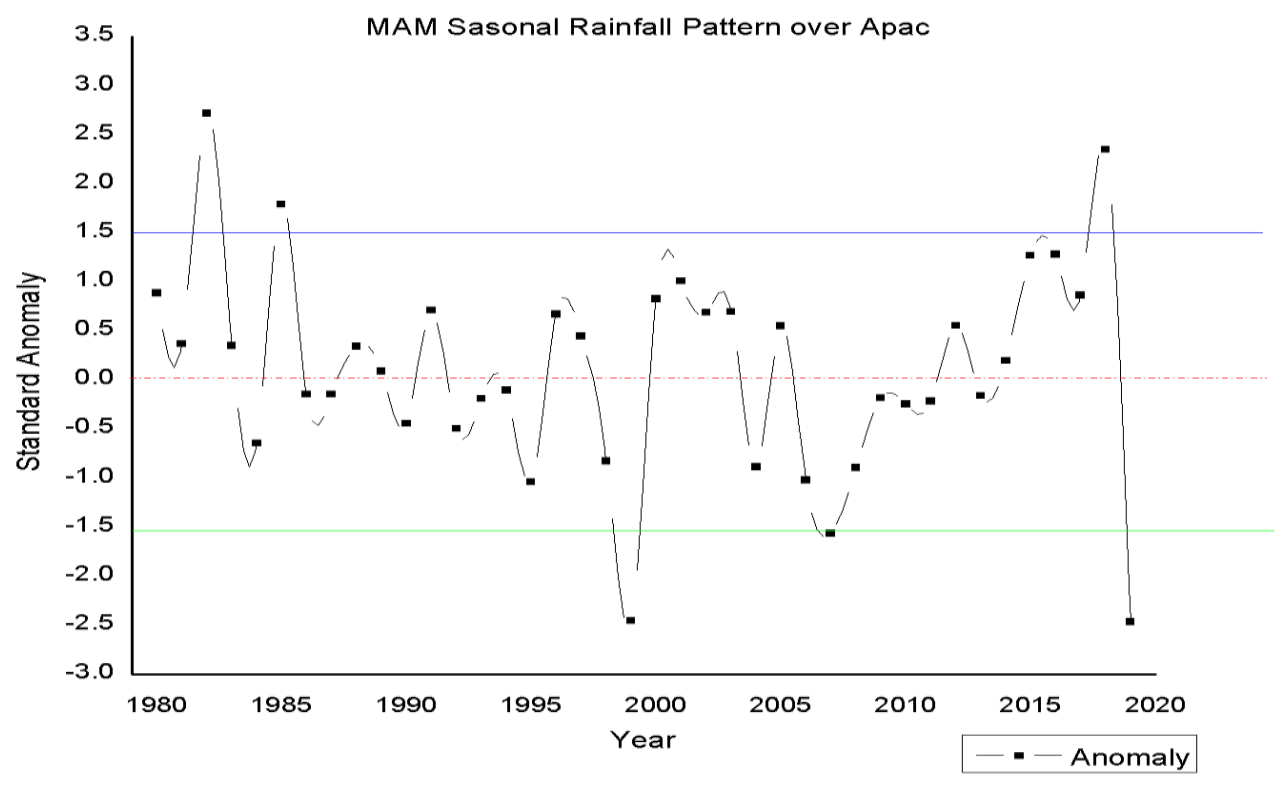

Fig. 1. MAM seasonal rainfall pattern over Apac district, Uganda from 1980 to 2019. 
301 The standard Anomaly of JJA rainfall pattern over Apac district was examined as illustrated in Fig. 2. The results indicate that the highest mean JJA rainfall over Apac district in the period 1980-2019 was observed in 1994 and 2007 which seem to have received the same amounts of rainfall (Extremely wet), while the least amount was noted in 2019 (extremely dry). However, based on the standard deviation of JJA rainfall of $\geq 1$ (for wet years) and $\leq$ 1(for dry years) (Ogwang et al. 2018), three wet years were observed during JJA over the study period, while three dry years were noted for the same study period (Fig. 2).

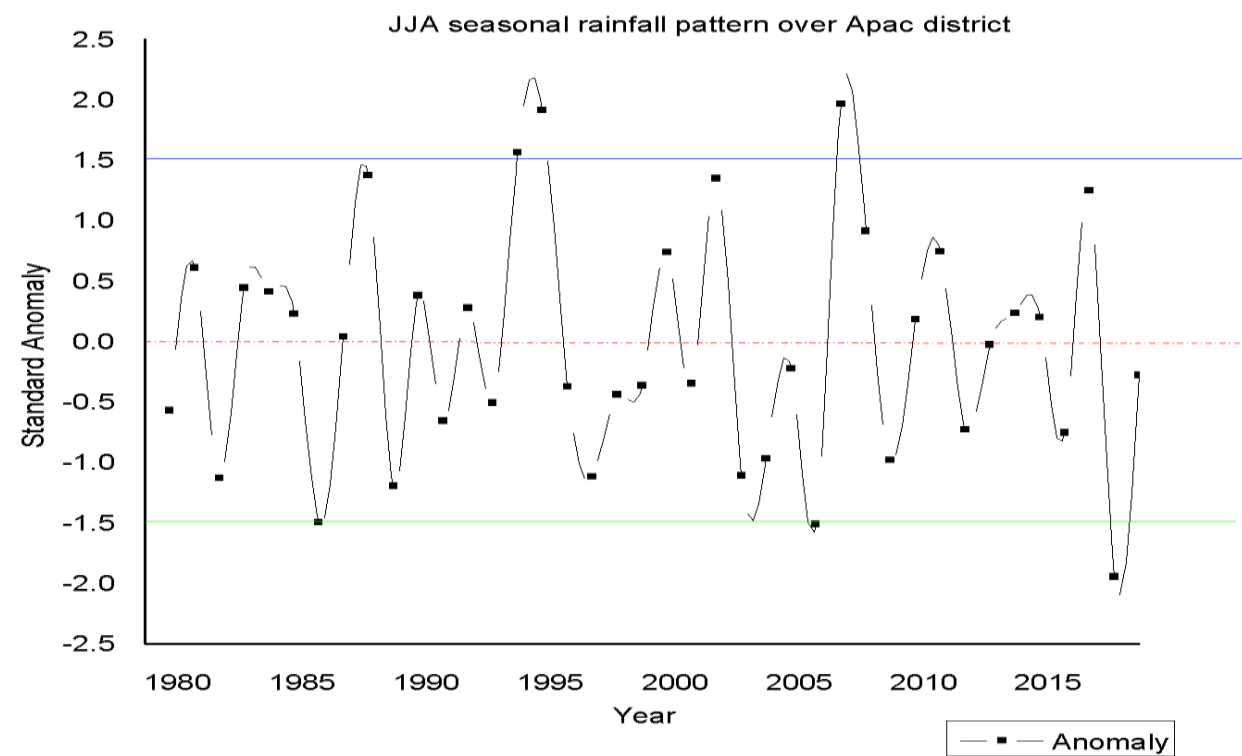

308

Fig. 2. JJA seasonal rainfall pattern in Apac district from 1980 to 2019.

The standard anomaly of SON rainfall (Fig. 3) showed that the highest mean SON rainfall over the period 1980-2019 was observed in 2019 (extremely wet), while the least amount was noted in 1981 (extremely dry year). Basing on the standard deviation of SON rainfall of $\geq 1$ (for wet years) and $\leq 1$ (for dry years), respectively (Ogwang et al. 2018), four wet years were observed over the study period, while three dry years were noted for the same study period (Fig. 3). 


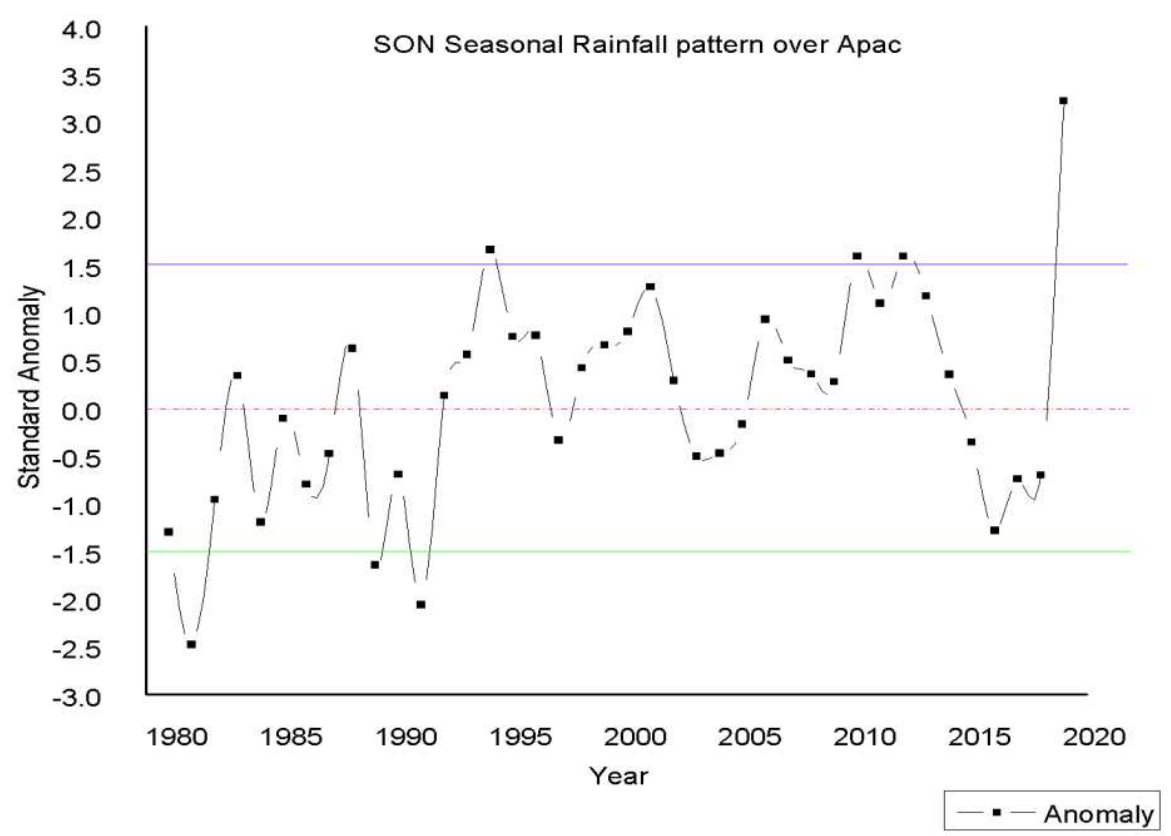

Figure 3. SON seasonal rainfall pattern in Apac district, Uganda from 1980 to 2019

\subsection{Seasonal rainfall trend of the study area}

The Mann-Kendall analysis of mean MAM, JJA and SON rainfall over Apac for 1980 to 2019 are illustrated in Fig. 4-6. The blue lines above (UL) and below (LL) and the dashed (dotted) lines represent critical values of $95 \%$ confidence interval. The sequential MannKendall test statistics are denoted as the forward regression (FR) and backward regression (BR).

\subsubsection{MAM}

Results of the Sequential Mann-Kendall test statistic for MAM seasonal rainfall over Apac (Fig. 4) considering the plot of $u\left(t_{i}\right)$ and $u^{\prime}\left(t_{i}\right)$ values for each of the months of the season (MAM) clearly indicated a decreasing trend in the mean MAM seasonal rainfall between 1982-1995. It also showed that from 1980 to 1982 , MAM seasonal rainfall varied within the mean. Thereafter, there was an abrupt change in trend in 1983 followed by a steady decline in rainfall trend in MAM. This decreasing trend became significant in 1985, 1999 and 2011. After 2011, the seasonal rain showed an increasing trend which was not significant but 
continued up to the end of the study period (see appendix 2). The changes in MAM rain season were also documented by Mubiru et al. (2012) where they note that the unseasonal periods (3-4 weeks) of no rain are becoming common in the unimodal rainfall receiving areas such as northern Uganda. Earlier studies (e.g., Okoola 1996; Camberlin et al. 2003) have associated these variations and abrupt changes in rainfall in Uganda with the large-scale global systems that control weather such as the El Nino South Oscillation (ENSO), cyclones and monsoons.

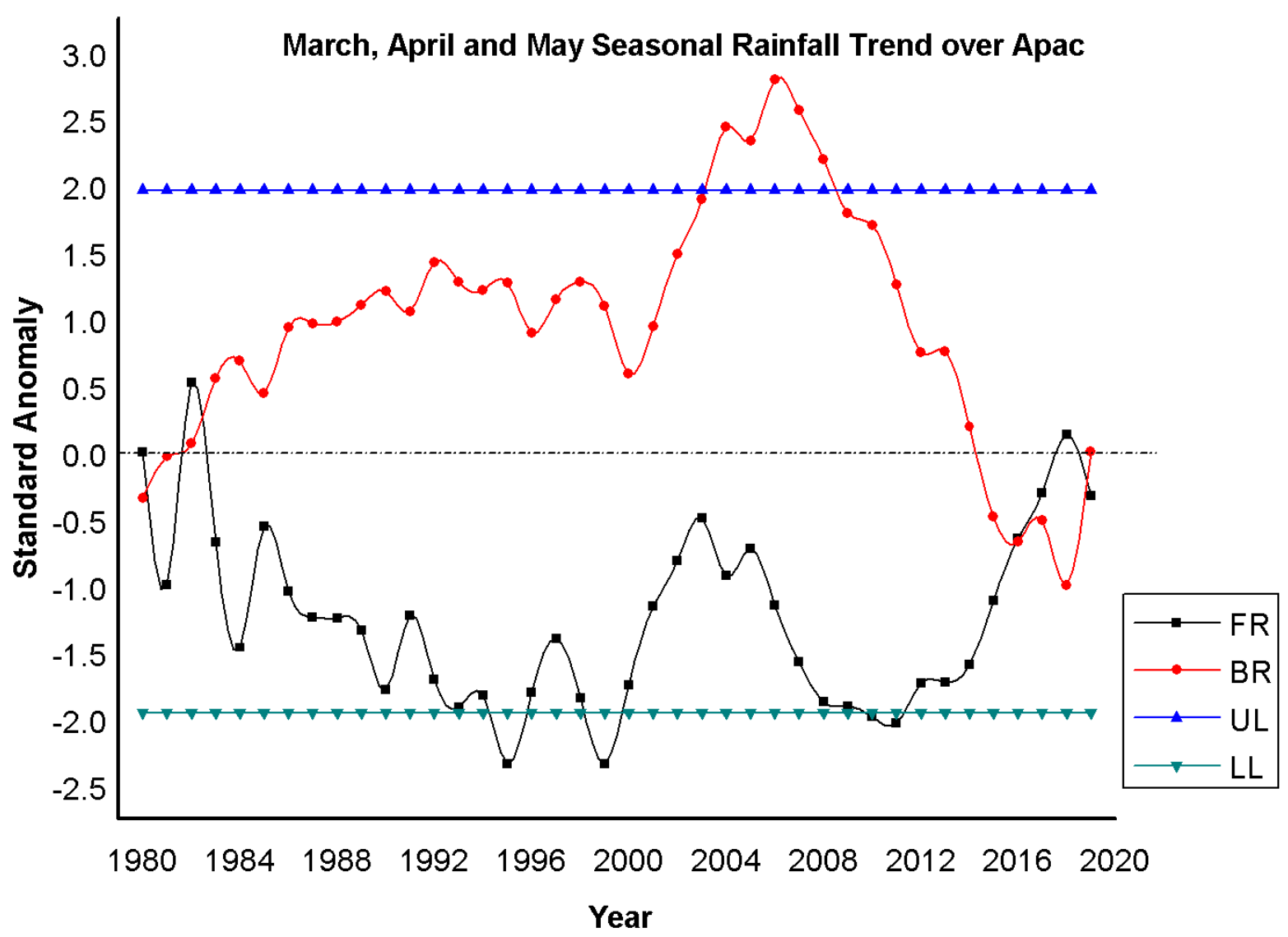

Figure 4. Changes in average March, April and May (MAM) seasonal rainfall in Apac district (1980-12019) as derived from sequential Mann-Kendall test statistics, $u\left(t_{i}\right)$ forward sequential statistics and $u^{\prime}\left(t_{i}\right)$ backward sequential statistic. $\mathrm{FR}=$ forward regression, $\mathrm{BR}=$ Backward regression, $\mathrm{UL}=$ Upper limit and $\mathrm{LL}=$ Lower limit. 


\subsubsection{JJA}

349 The forward $u\left(t_{i}\right)$ and backward $u$ '(t $\left.t_{i}\right)$ regression plots for the June, July and August season 350 rainfall (Fig. 5) displays variability within the mean with no decreasing nor increasing trend 351 in the seasonal rainfall. Overall, there was no observed increase nor decrease in JJA seasonal 352 rainfall trend. The pattern in (Fig. 5) shows variation within the mean monthly rainfall of the study area. A study of the East African seasonal rainfall (Ntale et al. 2003) reveals that there is a narrow coastal band starting from Madagascar reaching the northeastern coast of Africa extending to the west coast of India which is negatively correlated to precipitation. This is brought about by a buildup of cold Sea Surface Temperatures (SSTs) during JJA in the Indian ocean which probably reduces the amount of moisture in the north easterlies resulting to more or less average rains received by the region during JJA.

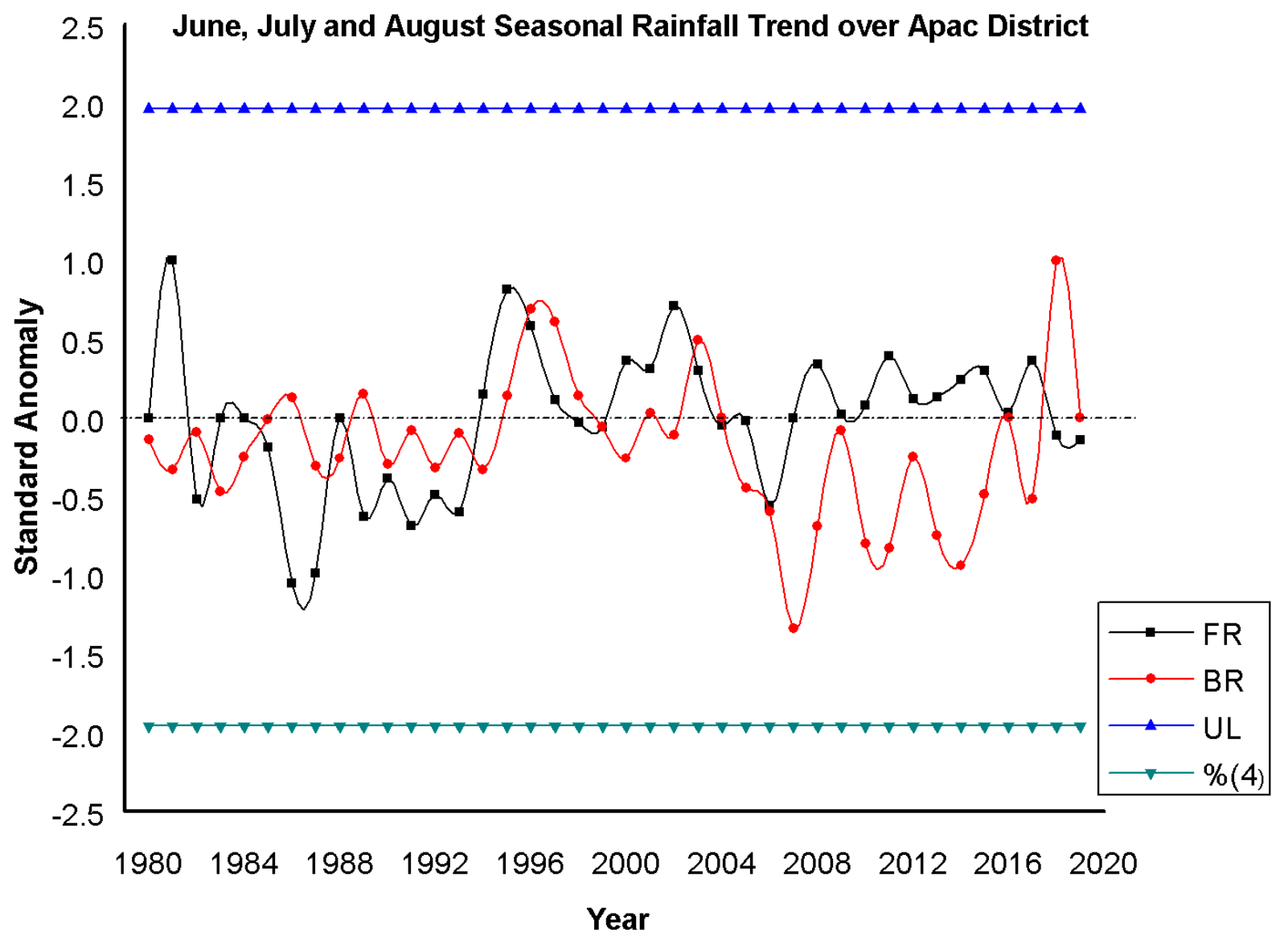


361 Figure 5. Change in average June, July and August (JJA) seasonal rainfall in Apac district 362 (1980-2019) derived from sequential Mann-Kendall test statistics, $u\left(t_{i}\right)$ forward sequential 363 statistics and $u^{\prime}\left(t_{i}\right)$ backward sequential statistic.

3.3.3 SON

366 Results from Mann-Kendal analysis (Fig. 6) indicated a general increasing trend in the SON 367 seasonal rainfall right from 1980 up to 2019. The increasing trend became significant in 1988 and thereafter decreases briefly till around 1991 and increases again till the end of the study period. The increase in trend became significant from 1986 up to the end of study period as shown by the curve beyond the level of significant test $(\mathrm{p}<0.05)$. Overall, SON seasonal rainfall over the study area displays increasing seasonal rainfall trend for the study period. This finding could be explained by a study by Ogwang et al (2016) which indicated a close relationship between SON rainfall anomaly over Uganda and the SON Sea Surface Temperatures (SST) anomaly over the Indian Ocean which captures the Indian Ocean Dipole (IOD) pattern, with significant positive and negative correlations in the western sector of the Indian Ocean and South Eastern part of the African continent. This means that the SON seasonal rainfall pattern is greatly influenced by the status of the IOD determined by the Indian Ocean Surface temperatures (temperature of the water surface of the Indian Ocean). Behera et al (2005) noted that the IOD has an overwhelming influence on the East African short rains from October to December. 


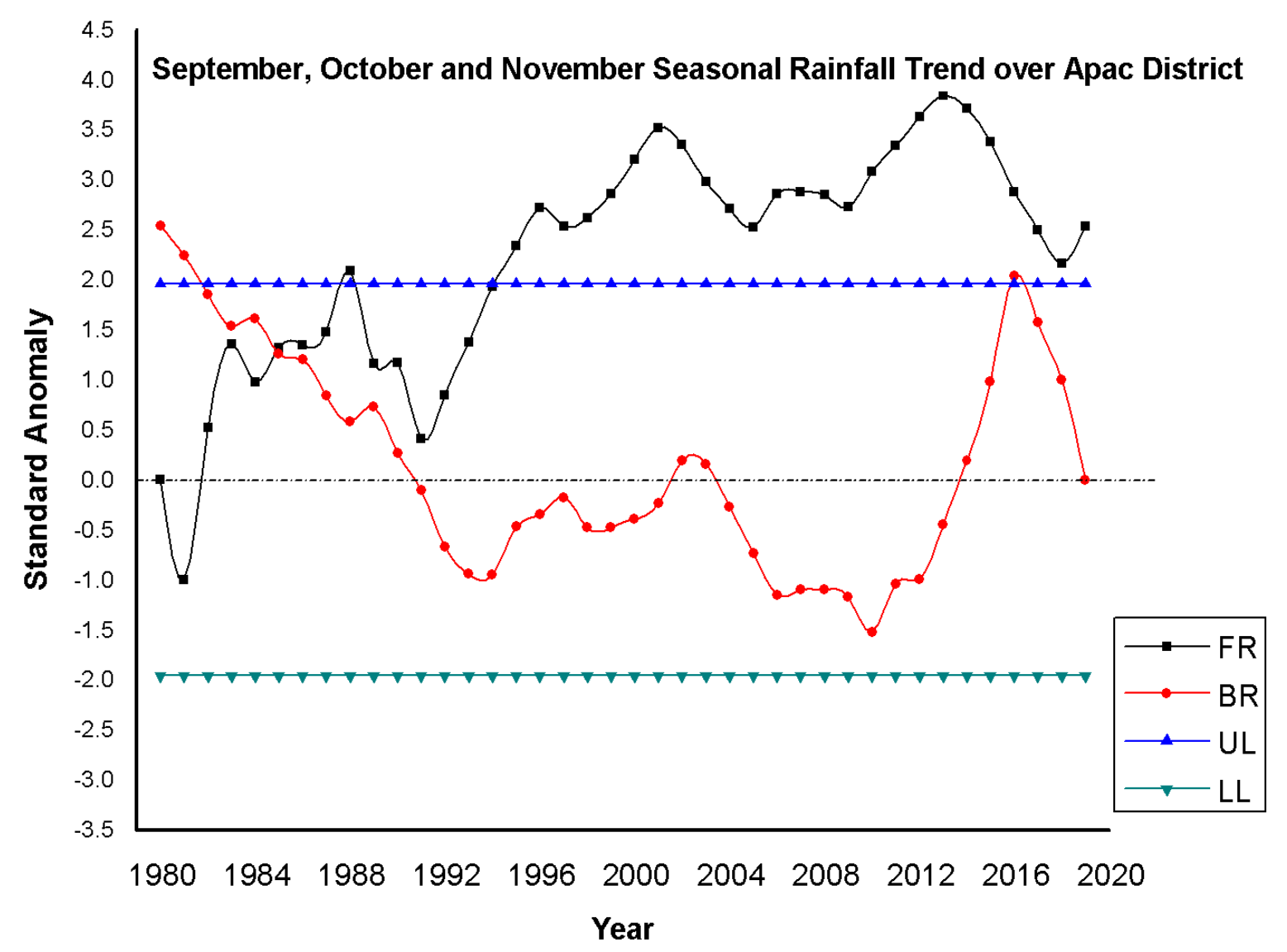

381

Figure 6. Change in average September, October and December (SON) seasonal rainfall over Apac district (1980-2019) as derived from sequential Mann-Kendall test statistics, $u\left(t_{i}\right)$ forward sequential statistics and $u^{\prime}\left(t_{i}\right)$ backward sequential statistic.

\section{Limitation of the study}

This study used only one rain gauge station meaning that there could be inaccurate spatially distributed precipitation data. However, this weakness was overcome by having rainfall records taken for a long period (Suresh et al. 2016).

\section{Conclusion}

392 This study analyzed long term rainfall time series of mean seasonal rainfall in Apac district for the last 39 years. The study reveals that mean seasonal rainfall for MAM and SON 
cropping seasons in Apac district showed high variability, from different time points within the past 39 years (1980-2019), while JJA has not had a significant change in rainfall within the same study period. Thus, the two cropping seasons (MAM and SON) in the district have experienced remarkable variations in rainfall. The first cropping season of MAM has experienced a significant decrease in rainfall with peaks experienced in 1995, 2009 and 2011 when Apac received rains below the lower limits of rains expected in the area. The most significant turning point for the MAM season over the years to start experiencing droughts was in 1982. The second cropping season of JJA according to this study experienced an insignificant variation in rainfall since the forward regression curve neither went below the lower limit nor the upper limit. That means this season (JJA) has been very supportive to farming in Apac. This study also revealed that the cropping season of SON in Apac generally for most of the period of study received much rainfall above the upper limit (Fig. 3). The much rains in SON season that enters deep into the dry months of December, January and February have a strong bearing on the crop farmers who would use the dry period to dry and process their farm produce. The increase of average rainfall within the SON season may have been as a result of migration of the overhead sun in the northern hemisphere resulting in these changes in rainfall over northern Uganda.

The seasonal rainfall information generated in this study offers opportunities to improve on farmer adaptation to the effects of climate change and increase crop yields through incorporation of the seasonal characteristics of the onset, cessation and length of the cropgrowing season. This information can also guide agricultural extension messages from extension agents to rural farmers.

\section{Declarations}

\section{Abbreviations}


UMA: Uganda Meteorological Authority; MAM: March, April, May; JJA: June July August; SON: September, October, November; ADB: African Development Bank; GUREC: Gulu University Research Ethics Committee; IPCC: Inter governmental Panel on Climate Change; UNCST: Uganda National Council of Science and Technology

\section{Ethics approval and consent to participate}

This study was approved by the Gulu University Research Ethics Committee (GUREC: GUREC -022-19) and the Uganda National Council of Science and Technology (UNCST). Written informed consent were obtained from all participants prior to data collection.

\section{Consent for publication: Not applicable}

Conflict of interests: The authors declare no competing interests.

Funding: This study was funded by the African Development Bank (ADB) through a doctoral scholarship to FA.

\section{Availability of data and materials}

The datasets used and/or analyzed during the current study is available from the corresponding author upon reasonable request.

\section{Author's contributions}

FA, GMM, MN, and IOU participated in designing the study; FA and OGW participated in collecting field data. FA, OGW DMO and GMM participated in analyzing and presenting the data. FA, GMM, BM, MN, DMO and IOU wrote the initial drafts of the manuscript. All the authors read and approved the final manuscript.

\section{Acknowledgements}


The work was partially supported by the African Development Bank (ADB) in their initiative to build the capacity of science lecturers at Gulu University. We thank Gulu University for providing an enabling environment for this study. We also extend our gratitude to the Gulu

445

University Research Ethics Committee (GUREC), Uganda National Council of Science and Technology (UNCST) and the office of the President of the Republic of Uganda for permission to conduct this study. Furthermore, we are grateful to the Uganda Meteorological Authority for providing data on rainfall records in Apac district for the period 1980 - 2019. We also acknowledge Zedekia Ezra Ocen for producing the map of the study area.

\section{References}

Anderson IMA, Robinson WI (2009) Karamoja livelihood programme (KALIP): Technical Reference Guide. Kampala: EU/ GOU/ FAO

Asadullah A, McIntyre NEIL \& Kigobe MAX (2008) Evaluation of five satellite products for estimation of rainfall over Uganda/Evaluation de cinq produits satellitaires pour l'estimation des précipitations en Ouganda. Hydrological Sciences Journal, 53(6):1137-1150

Atube, F., Malinga, G. M., Nyeko, M., Okello, D. M., Alarakol, S. P., \& Okello-Uma, I. (2021). Determinants of smallholder farmers' adaptation strategies to the effects of climate change: Evidence from northern Uganda. Agriculture \& Food Security, 10(1), $1-14$.

Auma S (2016) Land conflict, gender and agricultural production: a case of Apac District, Northern Uganda (Master's thesis, Norwegian University of Life Sciences, Ås) 
Bagamba F, Bashaasha B, Claessens I, Antle J (2012) Assessing climate change impacts and adaptation strategies for smallholder agricultural systems in Uganda. Afr Crop Sci J. 20:303-16.

Behera SK, Luo JJ, Masson S, Delecluse P, Gual-di S, Navarra A, Yamagata T (2005) Paramount Impact of the Indian Ocean Dipole on the East Af-rican Short Rains: A CGCM Study. Journal of Climate 18: 4514-4530

Camberlin P, Okoola RE (2003) The onset and cessation of the 'long rains' in Eastern Africa and their interannual variability. Theor Appl Climatol 75:43-54

Campozano, L., Célleri, R., Trachte, K., Bendix, J., \& Samaniego, E. (2016). Rainfall and cloud dynamics in the Andes: A southern Ecuador case study. Advances in Meteorology, 2016.

Chatterjee S, Bisai D, \& Khan A (2013) Detection of Approximate Potential Trend Turning Points in Temperature Time Series (1941-2010) for Asansol Weather Observation Station, West Bengal, India. Atmospheric and Climate Sciences, 2014

Chow VT, Maidment DR and Mays LW (1988) Applied Hydrology, Mc Graw Hill Book Company, ISBN 0-07-010810-2

Chris k, Jim R, Gary E, and Libby W (2012) Famine Early Warning Systems NetworkInforming Climate Change Adaptation Series; A Climate Trend Analysis of Uganda

Conway D (2005) From headwater tributaries to international river: Observing and adapting to climate variability and change in the Nile basin. Global Environmental Change, 15(2):99-114 
Esham M, Garforth C (2013) Agricultural adaptation to climate change: Insights from a farming community in Sri Lanka. Mitig Adapt Strateg Glob Chang. 18(5):535-49. https://doi.org/10.1007/s11027-012-9374-6

Fosu-Mensah BY, Vlek PL \& MacCarthy DS (2012) Farmers' perception and adaptation to climate change: a case study of Sekyedumase district in Ghana. Environment, Development and Sustainability, 14(4):495-505

Igodan CO, Gwary MM, Ekpere JA (1990) Critical skills and competency needs of extension agents: evidence from Nigeria. J Ext Syst. 6(1):100-7

Juana JS, Kahaka Z, \& Okurut FN (2013) Farmers' perceptions and adaptations to climate change in sub-Sahara Africa: A synthesis of empirical studies and implications for public policy in African agriculture. Journal of Agricultural Science, 5(4):121

Kamga AF, Ogwang AB, Kabengwela H, Dione C (2019) The State of Climate of Africa in 2018, ACMAD

Kerry H, Cook and Edward K, Vizy (2013) Projected Changes in East African Rainy Seasons. Journal of climate Vol.26

Krämer I, Borenäs K, Daschkeit A, Filies C, Haller I, Janßen H, Karstens S, Kule L, Lapinskis J, Varjopuro R (2013) Climate change impacts on infrastructure in the baltic sea region. Sectoral impact assessments for the baltic sea region-climate change impacts on biodiversity, fisheries, coastal infrastructure and tourism. Coast Reports.21:55-90

Marchant R, Mumbi C, Behera S, \& Yamagata T (2007) The Indian Ocean dipole-the unsung driver of climatic variability in East Africa. African Journal of Ecology, $45(1): 4-16$ 
Mendelsohn R (2006) The role of markets and governments in helping society adapt to a changing climate. Climate change. 78(1):203-15. https://doi.org/10.1007/s10584-006$\underline{9088-4}$

Mendelsohn R (2008) The impact of climate change on agriculture in developing countries. J Nat Resour Policy Res. 1(1):5-19. https://doi.org/10.1080/19390450802495882

Mubiru DN, Komutunga E, Agona A, Apok A, \& Ngara T (2012) Characterising agrometeorological climate risks and uncertainties: Crop production in Uganda. South African Journal of Science, 108(3-4):108-118

Mubiru DN, Kyazze FB, Radeny MA, Zziwa A, Lwasa J \& Kinyangi J (2015) Climatic trends, risk perceptions and coping strategies of smallholder farmers in rural Uganda

Mutai CC, Ward MN, Coleman AW (1998)Towards the prediction of the East Africa short rains based on sea-surface temperature-atmosphere coupling. Int J Climatol. 18:975997.http://dx.doi.org/10.1002/(SICI)10970088(199807)18:9<975::AIDJOC259>3.3.CO;2-L

Nimusiima A, Basalirwa CPK, Majaliwa JGM, Otim-Nape W, Okello-Onen J, RubaireAkiiki C, ... \& Ogwal-Byenek S (2013) Nature and dynamics of climate variability in the Uganda cattle corridor. African Journal of Environmental Science and Technology, 7(8):770-782

Ntale HK, Gan TY, \& Mwale D (2003) Prediction of East African seasonal rainfall using simplex canonical correlation analysis. Journal of Climate, 16(12):2105-2112

Ogallo LJ, (1988) Relationships between seasonal rainfall in East Africa and the Southern Oscillation. J Climatol. 8:31-43. http://dx.doi.org/10.1002/ joc.3370080104 
Ogwang BA, Kabengwela MH, Dione C, \& Kamga A (2018) The State of Climate of Africa in 2017. African Centre for Meteorological Applications for Development: Niamey, Niger

Okoola REA (1996) Space time characteristics of the ITCZ over equatorial Eastern Africa during anomalous years. MSc dissertation, Nairobi, University of Nairobi

Omondi PAO, Awange JL, Forootan E, Ogallo LA, Barakiza R, Girmaw GB, ... \& Kilavi M (2014) Changes in temperature and precipitation extremes over the Greater Horn of Africa region from 1961 to 2010. International Journal of Climatology, 34(4):12621277

Phillips J, McIntyre B (2000) ENSO and interannual rainfall variability in Uganda: Implications for agricultural management. Int J Climatol. 20:171-182

Rosegrant MW \& Cline SA (2003) Global food security: challenges and policies. Science, 302(5652):1917-1919

Schneider U, Fuchs T, Meyer-Christoffer A, \& Rudolf B, (2008) Global precipitation analysis products of the GPCC. Global Precipitation Climatology Centre (GPCC), DWD, Internet Publikation, 112

Steeg JVD, Herrero MT, Kinyangi J, Thornton PK, Rao KPC, Stern R \& Cooper PJ (2009) The influence of current and future climate-induced risk on the agricultural sector in East and Central Africa: Sensitizing the ASARECA strategic plan to climate change. ILRI

Suresh S, Puneet S, Xing F \& Latif K (2016) Hydrologic simulation approach for El Niño Southern Oscillation (ENSO)-affected watershed with limited raingauge stations, Hydrological Sciences Journal, 61:6, 991-1000, DOI:10.1080/02626667.2014.952640 
553

554

555

556

557

558

559

560

561

562

563

564

UBOS (2017) Statistical abstract [Online]. Available. https://www.ubos.org/wp-content/ uploads/publications/03_20182017_Statistical_Abstract.pdf, Accessed date: 6 April 2021

Uganda Bureau of Statistics (2016) The National Population and Housing census 2014-Main report

Wichern J, van Wijk MT, Descheemaeker K, Frelat R, van Asten PJ \& Giller KE (2017) Food availability and livelihood strategies among rural households across Uganda. Food security, 9(6):1385-1403

\section{Appendices}

Appendix 1: Standardized seasonal rainfall indices for MAM, JJA and SON

\begin{tabular}{|l|l|l|l|}
\hline Year & MAM & JJA & SON \\
\hline 1981 & 0.887248 & -0.57193 & -1.30008 \\
\hline 1982 & 0.372456 & 0.609075 & -2.47818 \\
\hline 1983 & 2.718361 & -1.12852 & -0.95953 \\
\hline 1984 & 0.349784 & 0.445614 & 0.340675 \\
\hline 1985 & -0.64646 & 0.412922 & -1.19991 \\
\hline 1986 & 1.790135 & 0.229391 & -0.10672 \\
\hline 1987 & -0.14515 & -1.49328 & -0.80022 \\
\hline 1988 & -0.14515 & 0.041169 & -0.48065 \\
\hline 1989 & 0.341782 & 1.373256 & 0.625899 \\
\hline 1990 & 0.091054 & -1.19472 & -1.64731 \\
\hline
\end{tabular}




\begin{tabular}{|c|c|c|c|}
\hline 1991 & -0.44241 & 0.382682 & -0.69243 \\
\hline 1992 & 0.712539 & -0.65448 & -2.06417 \\
\hline 1993 & -0.49576 & 0.278067 & 0.131766 \\
\hline 1994 & -0.18901 & -0.50573 & 0.561032 \\
\hline 1995 & -0.10366 & 1.56614 & 1.659955 \\
\hline 1996 & -1.03855 & 1.911861 & 0.74991 \\
\hline 1997 & 0.671196 & -0.37169 & 0.761357 \\
\hline 1998 & 0.449808 & -1.11626 & -0.33757 \\
\hline 1999 & -0.82517 & -0.43789 & 0.420805 \\
\hline 2000 & -2.45223 & -0.3627 & 0.661195 \\
\hline 2001 & 0.8259 & 0.739844 & 0.802376 \\
\hline 2002 & 1.009945 & -0.34635 & 1.270753 \\
\hline 2003 & 0.691201 & 1.350372 & 0.286302 \\
\hline 2004 & 0.699202 & -1.1089 & -0.50736 \\
\hline 2005 & -0.88518 & -0.96669 & -0.47589 \\
\hline 2006 & 0.551166 & -0.22376 & -0.17063 \\
\hline 2007 & -1.02255 & -1.50693 & 0.92734 \\
\hline 2008 & -1.56402 & 1.964168 & 0.501889 \\
\hline 2009 & -0.89319 & 0.913113 & 0.354984 \\
\hline 2010 & -0.18235 & -0.98222 & 0.273901 \\
\hline 2011 & -0.24369 & 0.182442 & 1.590417 \\
\hline 2012 & -0.21569 & 0.746383 & 1.098093 \\
\hline 2013 & 0.553834 & -0.72804 & 1.589364 \\
\hline 2014 & -0.15967 & -0.02515 & 1.172499 \\
\hline
\end{tabular}




\begin{tabular}{|l|l|l|l|}
2015 & 0.196413 & 0.234749 & 0.352123 \\
\hline 2016 & 1.270008 & 0.200423 & -0.35569 \\
\hline 2017 & 1.282011 & -0.75501 & -1.28768 \\
\hline 2018 & 0.864576 & 1.247391 & -0.74298 \\
\hline 2019 & 2.348938 & -1.94582 & -0.70483 \\
\hline 2020 & -2.4629 & -0.2777 & 3.220578 \\
\hline
\end{tabular}

565

566 Appendix 2: Change points in seasonal rainfall detected using Sequential Man-Kendall Test

567 for Apac district (Values significant at $\mathrm{p} \leq 0.05$ ).

\begin{tabular}{|c|c|c|c|c|c|c|c|c|c|c|c|c|c|}
\hline \multirow{2}{*}{$\begin{array}{l}\text { Seaso } \\
\mathbf{n}\end{array}$} & \multicolumn{12}{|c|}{ Detected change points } & \multirow[t]{2}{*}{ Remarks } \\
\hline & $1 \mathrm{st}$ & $2^{\text {nd }}$ & $3 \mathrm{rd}$ & 4 th & 5 th & 6th & 7 th & 8 th & 9th & 10th & 11th & 12th & \\
\hline MAM & 1981 & $\begin{array}{l}1982 \\
*\end{array}$ & $\begin{array}{l}2016 \\
*\end{array}$ & - & - & - & - & - & - & - & - & - & $\begin{array}{l}\text { *Significa } \\
\text { nt }\end{array}$ \\
\hline JJA & 1981 & 1982 & 1984 & $\begin{array}{l}198 \\
7\end{array}$ & $\begin{array}{l}198 \\
8\end{array}$ & $\begin{array}{l}199 \\
3\end{array}$ & $\begin{array}{l}199 \\
5\end{array}$ & $\begin{array}{l}199 \\
9\end{array}$ & $\begin{array}{l}200 \\
2\end{array}$ & 2003 & 2005 & 2017 & \\
\hline SON & - & - & - & - & - & - & - & - & - & - & - & - & \\
\hline
\end{tabular}

568 


\section{Figures}

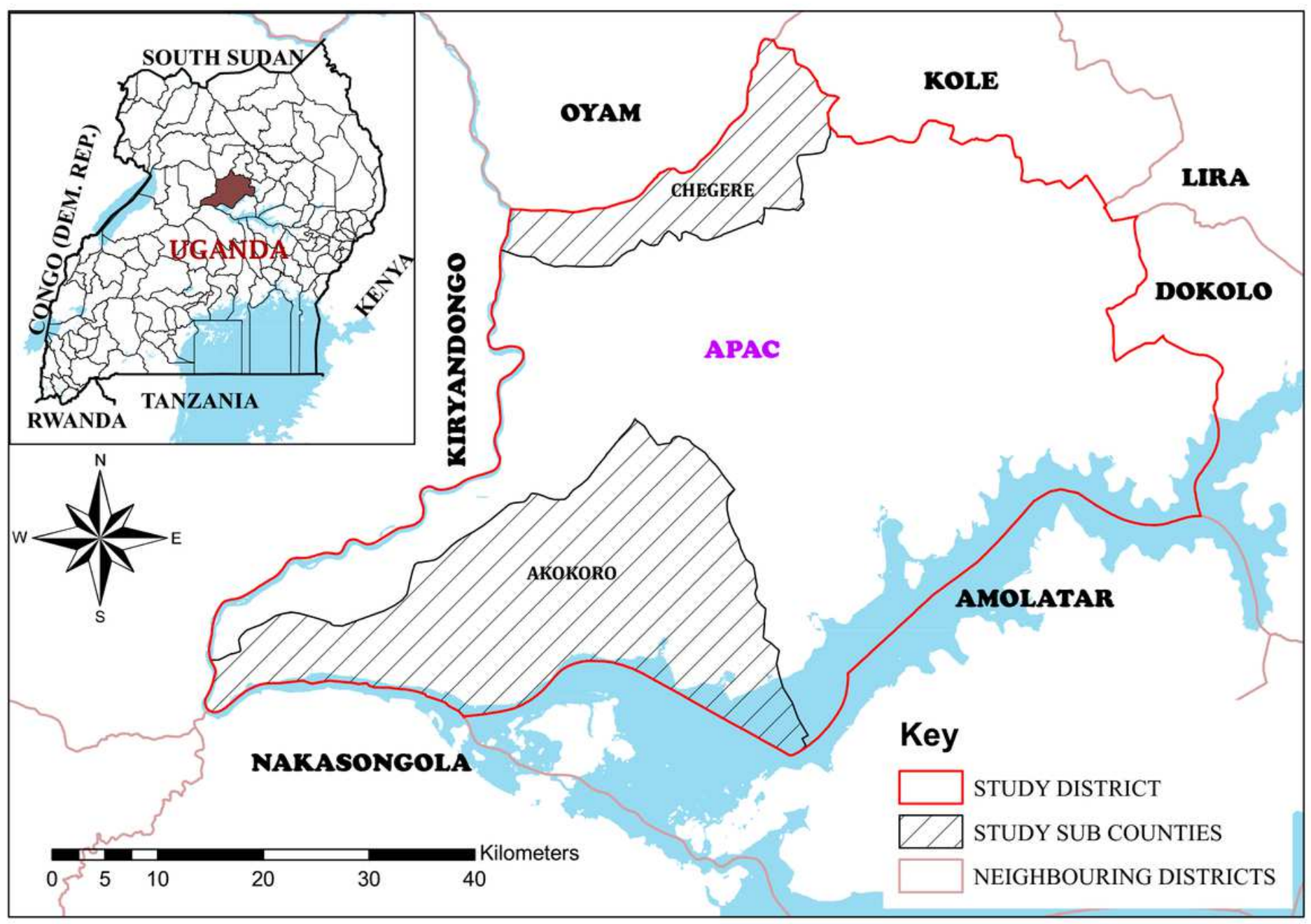

Figure 1

Location of Apac district in Uganda. Note: The designations employed and the presentation of the material on this map do not imply the expression of any opinion whatsoever on the part of Research Square concerning the legal status of any country, territory, city or area or of its authorities, or concerning the delimitation of its frontiers or boundaries. This map has been provided by the authors. 


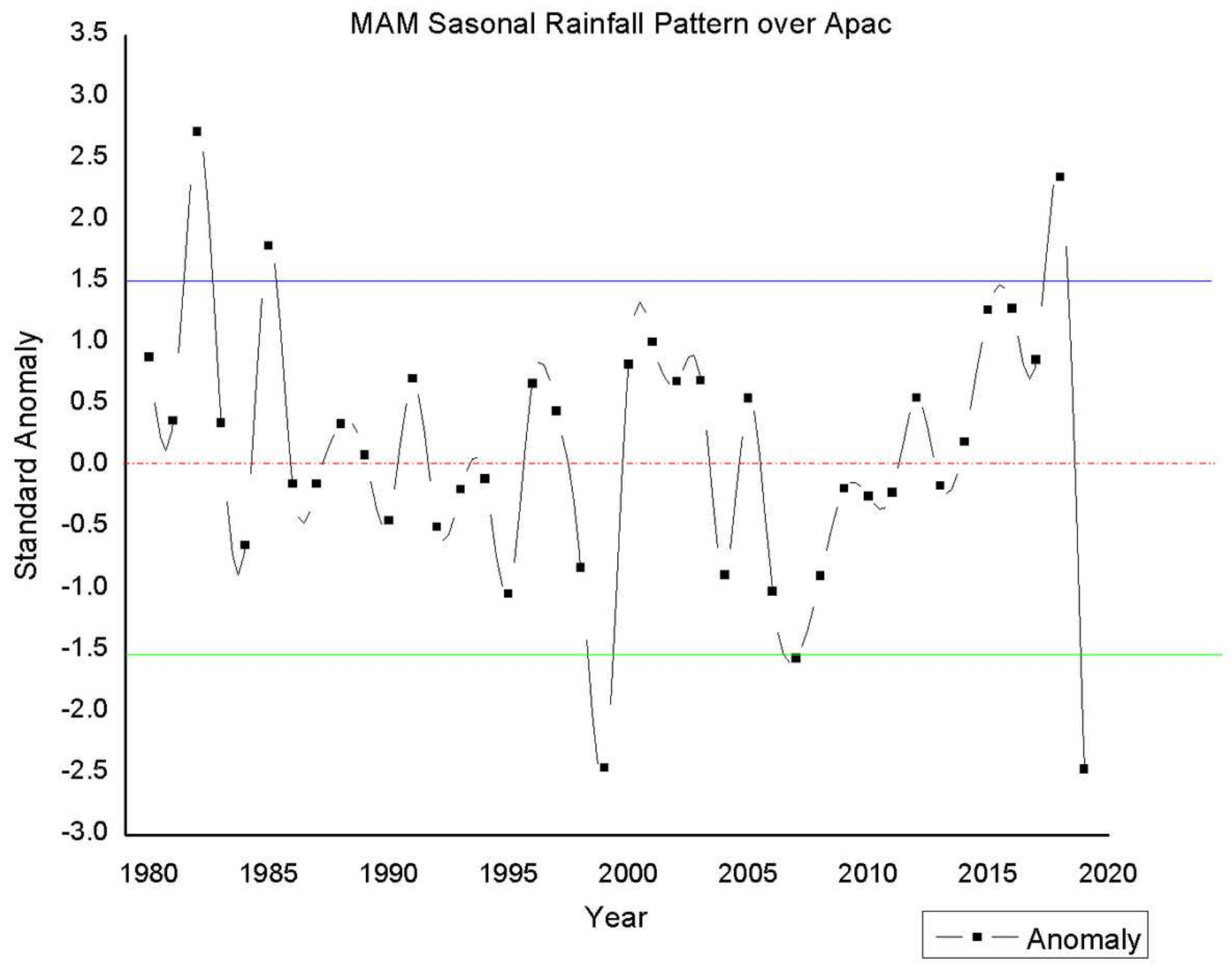

Figure 2

MAM seasonal rainfall pattern over Apac district, Uganda from 1980 to 2019. 


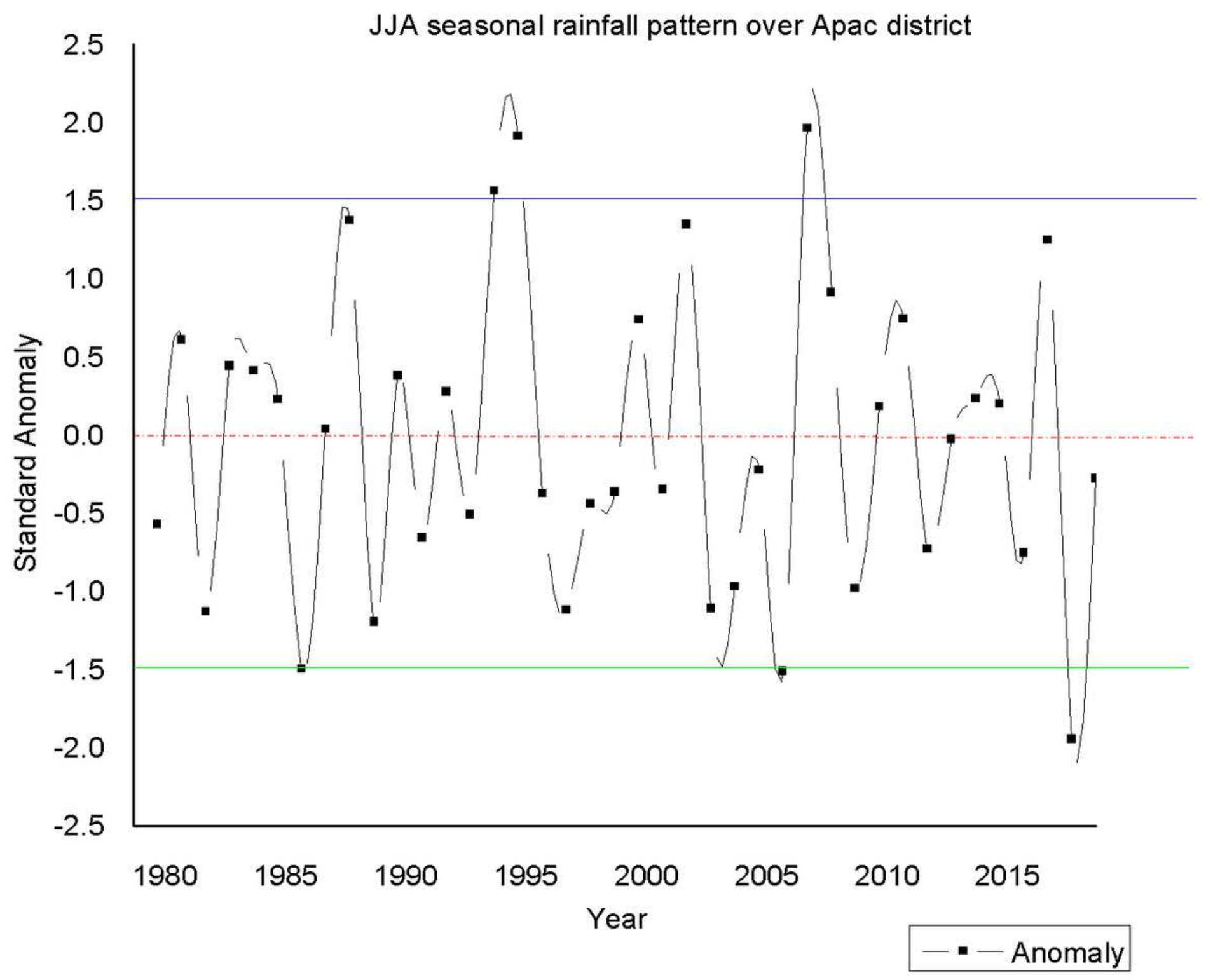

Figure 3

JJA seasonal rainfall pattern in Apac district from 1980 to 2019. 


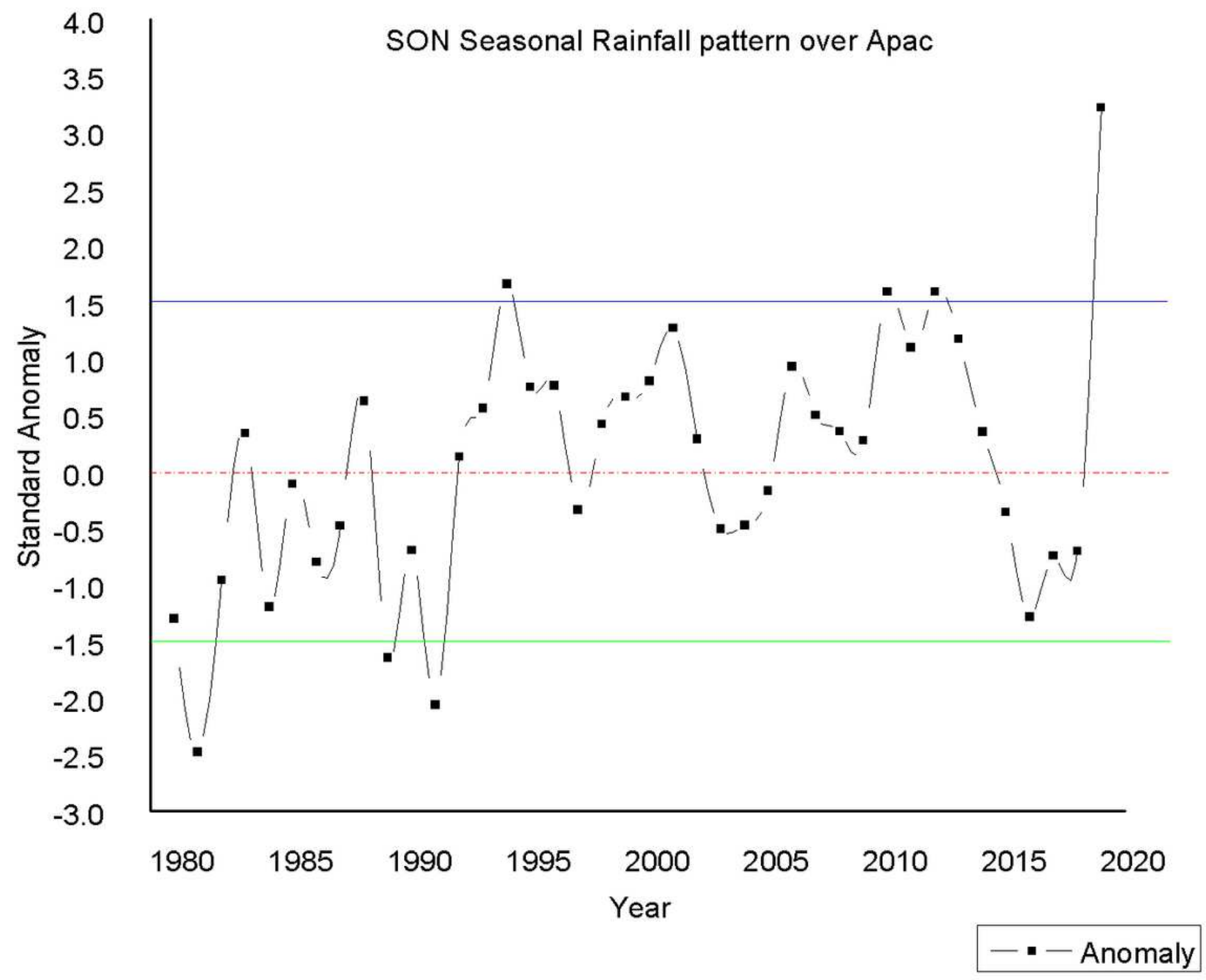

Figure 4

SON seasonal rainfall pattern in Apac district, Uganda from 1980 to 2019 


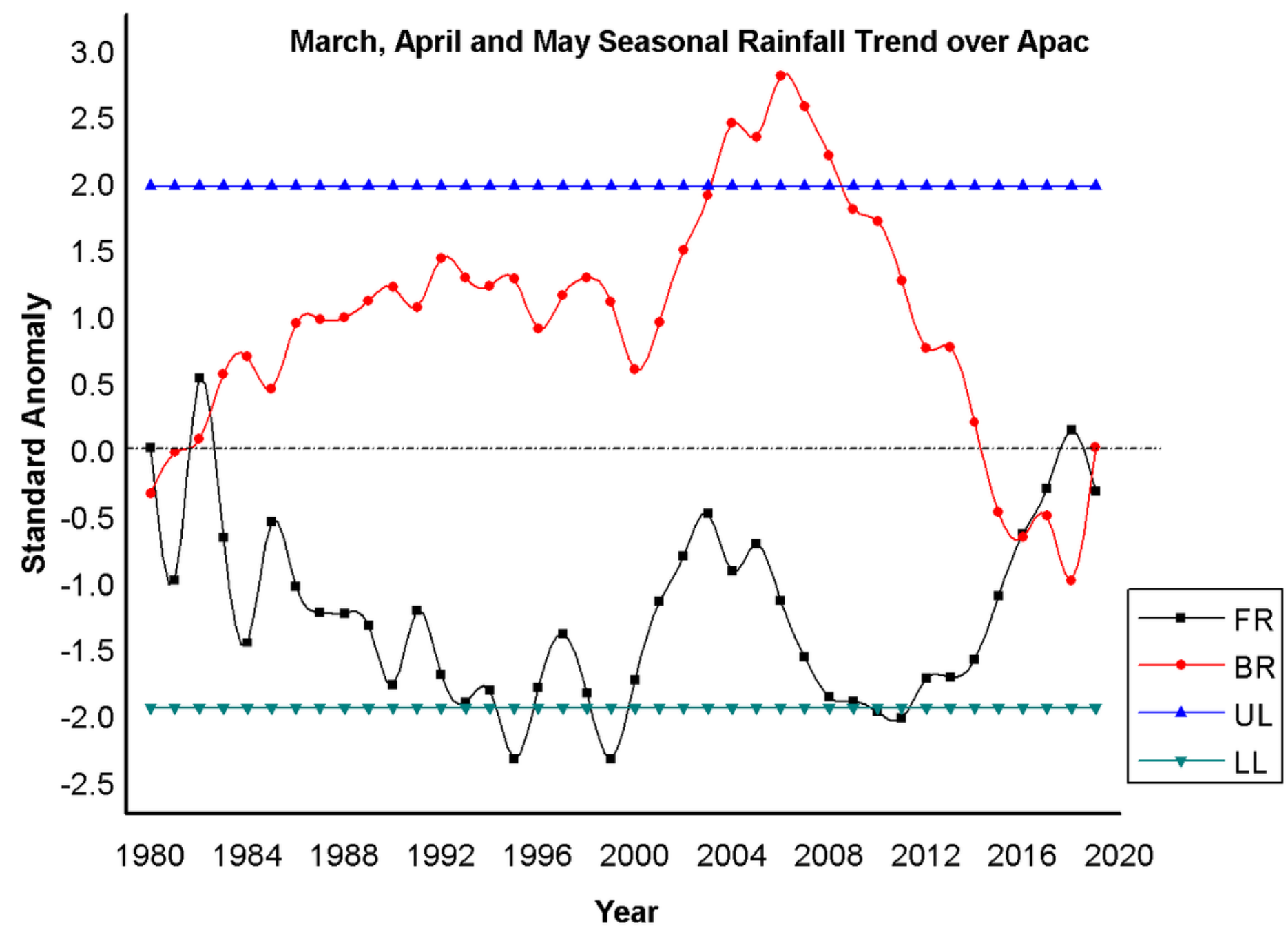

Figure 5

Changes in average March, April and May (MAM) seasonal rainfall in Apac district (1980-12019) as derived from sequential Mann-Kendall test statistics, u(ti) forward sequential statistics and u'(ti) backward sequential statistic. $\mathrm{FR}=$ forward regression, $\mathrm{BR}=$ Backward regression, $\mathrm{UL}=$ Upper limit and $\mathrm{LL}=$ Lower limit. 


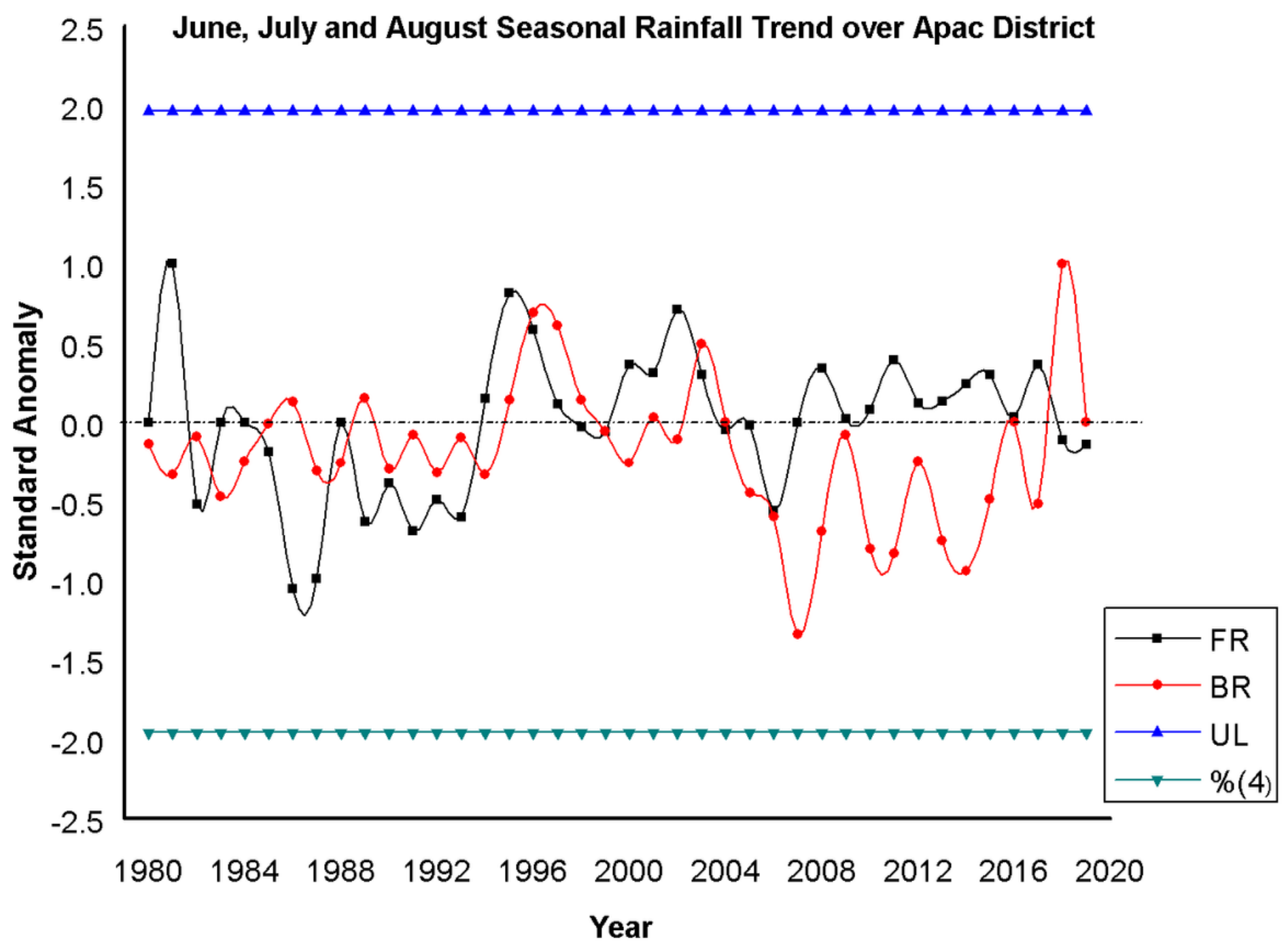

Figure 6

Change in average June, July and August (JJA) seasonal rainfall in Apac district (1980-2019) derived from sequential Mann-Kendall test statistics, u(ti) forward sequential statistics and u'(ti) backward sequential statistic. 


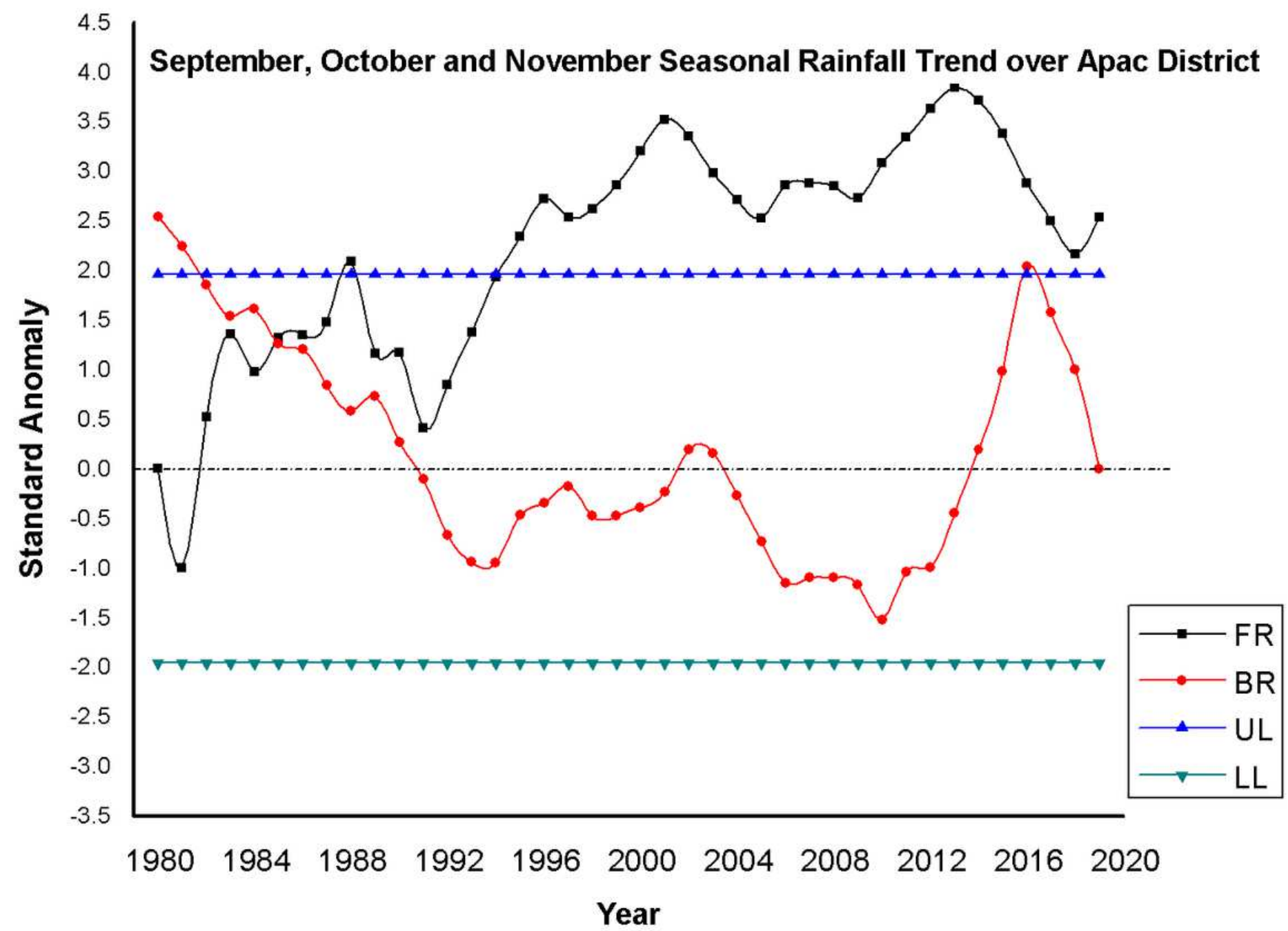

Figure 7

Change in average September, October and December (SON) seasonal rainfall over Apac district (19802019) as derived from sequential Mann-Kendall test statistics, u(ti) forward sequential statistics and $u^{\prime}(\mathrm{ti})$ backward sequential statistic. 